SAD / JSR

Sosyoloji Araştırmaları Dergisi / Journal of Sociological Research

Cilt / Volume 20 Sayı / Number 1 (Nisan / April 2017) : (201-236)

\title{
YAPILAŞMIŞ KIRSAL HABİTUSUN DEĞİşİII: ÜÇ KÖY OKUMASI
}

\author{
Pervin ŞENOL ${ }^{1}$ \\ N. Serpil ALTUNTEK ${ }^{2}$
}

\section{$\ddot{O Z Z}$}

Türkiye'de kentsel alanların yanı sıra kırsal alanlar da çok boyutlu değişim süreci içindedir. Bu çalışmada, değişime direnme, uyarlanma veya karşı stratejiler geliştirme biçimlerini anlayabilmek için modernleşmeci kuramdan ziyade bireyi aktif bir eyleyici olarak ele alan Pierre Bourdieu'nün eylem kuramının açımlayıcı perspektifine başvurulmuş; dışsal faktörlerin dönüştürücü etkinliği karşısında farklı kırsal yerleşmelerde eyleyicilerin geliştirdikleri uyarlanma stratejilerinin nasıl farklılık gösterdiği sorusuna üç farklı kırsal yerleşim örneği üzerinden yanıt aranmıştır. 2013-2016 yılları arasında derinlemesine görüşme ve doğrudan gözlem tekniklerini kullanarak gerçekleştirilen alan araştırmasında, Isparta ili Gönen ilçesine bağlı Kızılcık, Baladız (Gümüşün) ve İğdecik köylerindeki değişim farkı, bu yerleşimlerdeki eyleyicilerin tarihsel olarak içselleştirdiği eylem hatlarında ve sahip oldukları sermaye türüne ve hacmine dayanan uyarlanma stratejilerindeki farkta aranmıştır.

Anahtar Kelimeler: Kırsal Değişme, Kırsal Farklılıklar, Eylem Kuramı, Toplumsal Uzam, Pierre Bourdieu, Isparta

${ }^{1}$ Yrd. Doç. Dr. Süleyman Demirel Üniversitesi, Mimarlık Fakültesi, Şehir ve Bölge Planlama Bölümü ${ }^{2}$ Prof. Dr. Süleyman Demirel Üniversitesi, Fen-Edebiyat Fakültesi, Antropoloji Bölümü

SAD / JSR

Cilt / Volume 20 Sayı / Number 1 


\title{
A CHANGE IN THE STRUCTURED RURAL HABITUS: A READING OF THREE VILLAGES
}

\begin{abstract}
In Turkey, the rural areas are also undergoing a process of multidimensional change alongside the urban areas. Instead of the theory of modernization, the present study refers to the revealing perspective of Bourdieu's theory of action that treats the individual as an active agent in an attempt to understand forms of adaptation, resistance or developing counter-strategies to change. Furthermore, the present study seeks an answer to the question of how agents' adaptation strategies in different rural settings vary in response to the transformative activity of exogenous factors in three different rural settlement contexts. In the field research carried out using the in-depth interview and direct observation techniques between 2013 and 2016, the difference of change in the Kızılcık, Baladız (Gümüşgün), and İğdecik Villages, affiliated to Gönen district of Isparta province, was sought in the differences along the lines of action historically internalized by the local agents and in their strategies of adaptation based on the type and volume of the capital they had.
\end{abstract}

Keywords: Rural Change, Rural Differences, Theory of Action, Social Space, Pierre Bourdieu, Isparta 


\section{GİRIŞ ${ }^{3}$}

Türkiye'de kırsal alanlarda gözlenen çok boyutlu değişim son yıllardaki en dikkat çekici gelişmeler arasındadır. Bu değişmeye, erken dönem kırsal araştırmaların benimsediği gibi klasik modernleşme kuramının tek yönlü değişim modeliyle yaklaşmanın yetersiz olduğu açıktır. Şöyle ki; modernleşme kuramı, modernin / kentin kır üzerinde etkisi olduğu, değişimin bir ölçüde "kendiliğinden" kente ve moderne yöneleceği şeklindeki ön kabulden hareket ederek, toplumsal - mekânsal değişim süreçlerini ilerlemeci, üst-belirlenimci bir yaklaşımla ele almakta; değişme sürecinde aktörlere genellikle pasif ve edilgin bir rol atfetmektedir (bkz. Akşit, 2006). ${ }^{4}$ Böyle bir model, toplumsal yapı ve süreçlerde ortaya çıkan farklılıkları; değişime direnme, uyarlanma veya karşı stratejiler geliştirme biçimlerini anlama ve açıklama imkânını kaçınılmaz olarak sınırlamaktadır. Dolayısıyla bireyi pasif bir aktör olarak değil de, aktif bir eyleyici olarak ele alan Bourdieu'nün (1995) eylem kuramının yapılaşma süreçlerini diyalektik bir ilişki içinde anlamamıza olanak sağlayacağı düşüncesiyle, bu çalışmada; dışsal faktörlerin dönüştürücü etkinliği karşısında farklı kırsal yerleşmelerde eyleyicilerin geliştirdikleri uyarlanma stratejilerinin nasıl farklılık gösterdiği sorusuna, üç farklı kırsal yerleşim örneği üzerinden, Bourdieucü bir perspektifle yanıt aranmaktadır. Bir başka deyişle, aynı coğrafyadaki modernleştirici planlar ve uygulamalara karşı lineer bir aks üzerinde birbirine yakın konumda olan Isparta ili Gönen ilçesine bağl1 Kızılcık, Baladız (Gümüşgün) ve İğdecik köylerinde gözlenen değişim farkı, bu yerleşimlerdeki eyleyicilerin tarihsel olarak içselleştirdiği eylem hatlarında ve sahip oldukları sermaye türüne ve hacmine dayanan uyarlanma stratejilerindeki farkta aranacaktır.

\footnotetext{
3 “21. Yüzyıl Penceresinden Kültür ve Kimlik Sempozyumu”nda (26-28 Mayıs 2014, Bakü) 2013 yılında gerçekleştirilen keşfedici araştırmanın ilk bulgularının sözlü sunumu yapılmıştır.

${ }^{4}$ Akşit (2006: 125-26), 1923-1950 yılları arasında gerçekleştirilen erken dönem kırsal araştırmalarda Kadro Mecmuası çevresinin kapitalizmin etkisi altında kırsal iktisadın değişimini sorunlaştırırken, A.Ü. Dil, Tarih ve Coğrafya Fakültesi çevresinin, kırsal kalkınmanın kentleşme ile yakından ilişkili olduğu düşüncesini benimsediğini belirtmektedir. Modernleşme kuramını kendine temel alan araştırmaların dışında, bu makalenin sorunsalı açısından, kırsal değişimde makro politikaların etkisini kabul etmekle birlikte kırsal alanların yapısal özelliklerini (köylülüğün farklılaşmış çıkarları, vb) analizlerine dâhil eden Birtek ve Keyder'in (1976) çalışması dikkate değerdir.
}

$\mathrm{SAD} / \mathrm{JSR}$

Cilt / Volume 20 Sayı / Number 1 
Bu üç köy, Gönen ilçesinin köylerinde gerçekleştirilen keşfedici bir araştırmanın sonucunda, karşılaştırma unsurları bakımından tarihsel-kültürel farklılıkları, toprak mülkiyetini edinme biçimleri, demografik özellikleri, büyük ölçekli yatırımlarla (kamu-özel) karşılaşma düzeyleri, yönetsel süreçlerle eklemlenme biçimleri göz önünde bulundurularak seçilmiş; şehir ve bölge planlaması ve sosyal/kültürel antropolojiyi birbirine yaklaştıracak şekilde, disiplinler arası bir perspektifle ele alınmıştır.

\section{Bourdieucü Okumanın Anahtar Kavramları}

Bourdieu'nun eylem kuramının en temel özelliği eylem ve yapıyı bir arada açıklayabilecek bir sentez olmasıdır (Tatlıcan ve Çeğin, 2007:305). Bu kuramda bireysel olanın "toplumsal öznelliği” olarak tanımlanan habitus kavramının merkezi bir yeri vardır. Ona göre, düşüncelerde ve eylemlerde algı, beğeni ve eylem şemalarını devreye sokan habitus, hem yapılanmış hem de yapılandırıcı bir mekanizmadır (Bourdieu ve Wacquant, 2003:27, 116-117). Bir grubun üyelerinin paylaştığı ortak deneyimleri sağlayan habitus, toplumsal bir topografya üzerinde temellenir ve paylaşılan bu toplumsal ortam, Bourdieu'nün ifade ettiği şekliyle, "alan"dır (Tatlıcan ve Çeğin, 2007:318). Bu çerçevede, alanlar kendi içsel mantı̆̆ına göre işleyen ve kendi ayırıcı yapıları ve dinamikleri olan görece özerk bir tür toplumsal mikro evrenlerdir (Emirbayer ve Williams, 2005:690). Buna göre, toplumsal sınıflar, meslek örgütleri, eğitim kurumları, siyasal partiler, vb. birer alan örnekleridirler.

Toplumsal yapılar statik, sabitlenmiş değildirler; çünkü habitus eyleyicilerin çeşitli durumlarla başa çıkmasına imkân veren strateji üretmesini de sağlamaktadır. Bir başka deyişle, her eyleyicinin ya da grubun belli bir alanda belirli bir konumu ve özel sermaye donanımları (ekonomik, sosyal, kültürel, simgesel) vardır. Farklı konumları işgal edenler arasında toplumsal bir mücadele gerçekleşirken aynı zamanda toplumsal yapı da dönüşür. Bu mücadele sırasında eyleyicilerin stratejileri, "alanın içinde durdukları noktadan alana bakış açılarına bağlıdır" (Bourdieu ve Wacquant, 2003:87). Bu nedenle aynı ortak 
deneyimleri paylaşsalar da aynı alan içinde mücadele eden eyleyicilerin stratejileri diğerinden farklı olacaktır.

Bununla birlikte, strateji veya eylem hatları habitus tarafından yapılandıklarından toplumsal olarak anlaşılabilir, tutarlı örüntüler oluşturmaktadır (Bourdieu ve Wacquant, 2003:31). Bourdieu tarafından bu örüntüler üç farklı alan stratejisi olarak ele alınır: Koruma, takip ve altüst etme. Alan mücadelesi genellikle hâkim konumdakiler ile tabi konumdakiler arasında geçer. Alana daha erken katılmış olanlar daha fazla sermaye biriktirmiş olmaları nedeniyle daha savunmacı konumdadırlar ve radikal çıkışlara, değişimlere karşı temkinlidirler; oysa yeni girenler takip stratejisini benimseyerek, baskın grupların sabit kanaatlerini, konumlarını sarsmak üzere uygun firsatları kullanmaya çalışırlar; altüst etme stratejisi ise alandaki marjinal gruplarca benimsenmiştir ve alanın meşruiyetini en fazla sorgulayanlar da onlardır (Swartz, 1997:125; Kaya, 2007:401).

Eylem kuramına göre, sermaye biçimleri ve toplam hacimleri eyleyiciler arasında belli bir mesafe/ ayrım yaratır. Eyleyiciler özellikle ekonomik sermaye ve kültürel sermayeye göre birbirlerinden ne kadar uzaklarsa o kadar az şeyi paylaşırlar (Bourdieu, 1995). Bu mesafenin veya ayrımın görünebilir olduğu, toplumsal olarak anlamlı farklılığa dönüştüğü durumu, Bourdieu "toplumsal uzam" olarak tanımlamaktadır.

Bu kavramlaştırmadan hareketle, farklı toplumsal alanlara ilişkin mücadelelerin bir arenası olan kentsel yerleşimlere karşın, kırsal yerleşimlerde toplumsal uzamların anlamlı bir farklılığa dönüşmediği düşünülerek, bu türden yerleşimlerin Bourdieucü bir analize uygun olmadığı ileri sürülebilir. Ancak Bourdieu, Fransa'daki Béarn bölgesinde yaptığı erken dönem kırsal sosyolojik çalışmasında, köylülerin kasabalıların sunduğu hizmetlere bağımlı olsalar da onlarla aralarındaki kültürel mesafeye dikkat çekerek, bu gerilimli ilişkiyi dil ayrımına bağlamaktadır (Savage, 2011; Bourdieu, 2009). Bu durumu sadece kasabaköy gibi farklı üretim yapı ve ilişkilerinin olduğu mekânlar arasında değil, bu araştırmada ele alındı̆̆g gibi, aynı mekânda da toplumsal uzam ayrımını görmek mümkündür. Dolayısıyla aynı coğrafi bölgede bulunan 
üç köyün analiz edildiği bu çalışmada, Bourdieu'nun toplumsal uzam kavramı, farklı sermaye tür ve hacmine sahip olan eyleyicilerin birbirlerinden toplumsal olarak farklılaşmasının belirginleştiği, görünür olduğu durumlar için kullanılacaktır.

\section{YÖNTEM}

Isparta' da üç köyün değişme sürecine odaklanan alan araştırması 2013-2016 yılları arasında yürütülmüştür. $\mathrm{Bu}$ köyler kendi içinde bütünlüğü olan, atomize yapılar olarak ele alınmamış, tersine, çağdaş dünya sisteminin bir parçası olarak çevreleriyle (mekânsal, sosyal, ekonomik açıdan) sürekli ilişki-etkileşim halinde oldukları varsayılmıştır. Dolayısıyla sosyal inşacı/ yorumcu bir yaklaşımla kırsal değişme sürecinin izinden giderken, araştırma üç köyle sınırlı kalmamış; köy sakinlerinin Gönen, Isparta ve Ankara'da yaşayan bazı akrabaları/ tanışları ve köy-dışına çeşitli nedenlerle göç etmiş eski sakinleri de araştırmanın görüşmecileri arasında yer almışlardır. Bu nedenle veri toplama süreci çok-mevkili (multi-sited) bir alanda gerçekleştirilmiştir (Marcus, 1995).

$\mathrm{Bu}$ çalışmanın verileri, doğrudan gözleme ve kartopu tekniği kullanarak toplam 52 kişiyle yapılmış görüşmelere dayanmaktadır. Görüşmecilerin olaylara bakış açılarını anlamaya yönelik yapılandırılmamış, açık uçlu derinlemesine görüşmeler doğal ortamda gerçekleştirilmiştir. Bu çalışmada antropolojik nitel araştırmanın gereği olarak görüşmeciler nicelleştirilmemiş, onların anlatıları üzerinden değişmeye yönelik tarihsel bir okuma yapılmıştır.

\section{ARAŞTIRMA ALANI}

Kızılcık, Baladız (Gümüşgün) ve İğdecik köyleri Isparta-Afyon karayolunun kuzeyinde, eski ulaşım olanakları göz önünde bulundurulduğunda, lineer bir aks üzerindedir (Şekil 1). Her üç köyde de geleneksel kırsal konut dokusu kuzey yamaçlardadır ve güneye (ovaya) doğru yayılma eğilimindedir; yayılma alanlarında modern konut malzeme ve teknolojilerinin kullanıldığı gözlemlenmiştir. Kızılcık köyü, kendisini Güneykent ve İğdecik’e bağlayan yolunun kullanılamayacak kadar bakımsız hale gelmesi sonucu 
tüm yerleşmelerle olan ulaşımını Gönen İlçe merkezi üzerinden gerçekleştirmektedir. Köy sınırları içinde yer alan tek yatırım, Kızılcık Göleti'dir. Baladız köyü Isparta, Burdur, Afyon illerini birbirine bağlayan karayolunun kavşak noktasında yer almaktadır. 1911 yılında hayata geçen Baladız demiryolu istasyonu uzun süre bölgenin ulaşım ağında önemli bir işlev üstlenmiştir. Köyün güneybatısındaki arazileri üzerinde Isparta Organize Sanayi Bölgesi (1992), Süleyman Demirel Havaalanı (1997) gibi büyük ölçekli kamu yatırımları yer almaktadır (Şekil 1). İğdecik ise, tarihsel olarak demiryolu ve karayolu olanaklarına sahiptir. Köyün Isparta-Afyon karayolu üzerindeki Göltaş Çimento Fabrikası'na (1968) yakınlı̆̆ı, sadece İğdeciklilere değil, çevre köylere de alternatif bir iş alanı oluşturmaktadır.

\section{Şekil 1: Kızılcık, Baladız (Gümüşgün) ve İğdecik Köy Konumları}

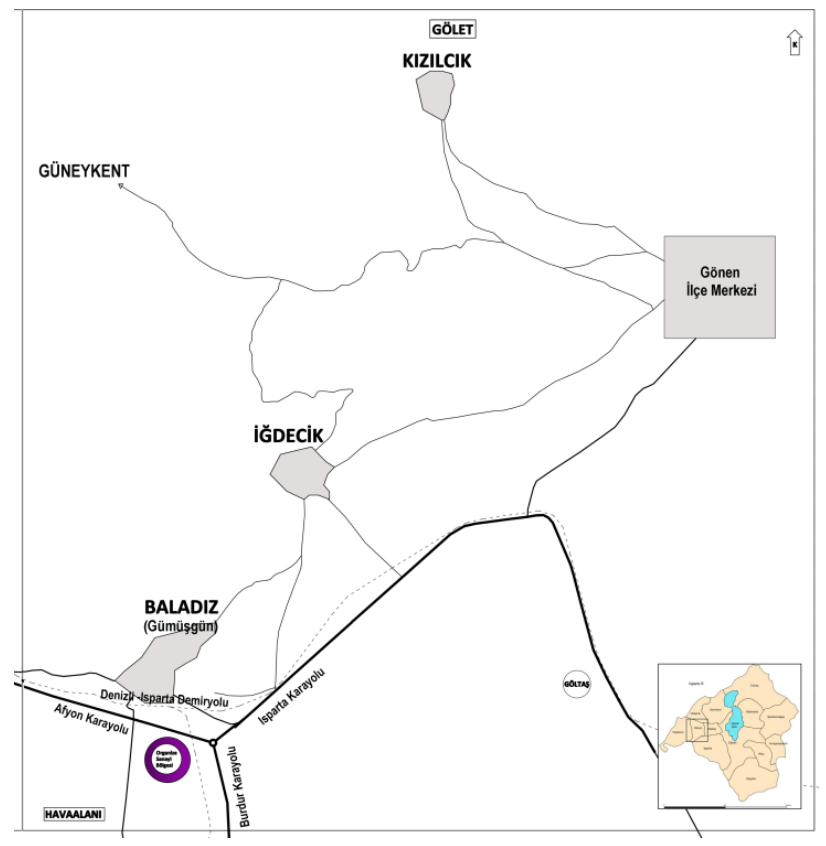

$\mathrm{SAD} / \mathrm{JSR}$

Cilt / Volume 20 Say / Number 1 


\section{ÜÇ KÖY, ÜÇ OKUMA DENEMESİ}

\section{Kızılcık Köyü: 'Bir Alan Savunusu Olarak Yörüklük'}

Sarıkeçili Yörük kültürünün ve göçebe-çobanlık pratiklerinden yerleşik kırsal yaşama geçişin bir örneği olan Kızılcık Köyü, içselleştirdiği habitusu ile diğer köylerden farklı olduğunun bilincindedir ve bu durum kendi ifadelerinde de yer bulmaktadır: 'Eskiden bura[da] tamamen göçebe olarak yaşıyorlarmış... Ben de çadırda kaldım; köyde evimiz vardı ama sürüden dolayı çobanlık yapıldı.' Görüşmecinin dediği gibi, göçebelik belki bir zamanlar temel yaşam tarzıydı ama yaylayıcılıkla bunu kısmen yaşatan ailelerin varlı̆̆ı, bazılarının toplumsal belleğinde göçebe yaşamının canlılı̆̆ını koruması, bazılarının günlük pratiklerinde işlerliğini sürdürmesi, Kızılcık köyünü araştırmanın odağındaki diğer köylerden ayırıcı en temel özelliğidir. Bourdieucü bir ifadeyle, göçebeliğin yapılaştırıcı bir habitus olarak bir tarihselliği vardır.

Osmanlı coğrafyasının önemli unsurlarından olan konar-göçerler, mevsimine göre yaylak ve kışlak alanları arasında dikey veya yatay olarak hareket eden çoban topluluklarıdır. Temel geçim örüntüsü sürü hayvanlarının üretimine ve bunların ürünlerinden yararlanmaya dayanan çobanlık, ileri düzeyde bir arazi kullanım stratejisini ve aynı zamanda yerleşiklerle belirli düzeyde iletişimi ve alışverişi gerektirmektedir (Bates, 2009: 189-190). Bununla birlikte, bazı konar-göçer grupların kışlak alanlarda kendi ihtiyaçlarını karşılayabilmek veya pazarlamak amacıyla tarımla uğraştıkları, bağcılık ve arıcılık yaptıkları, ihraç malı olarak halı ve kilim ürettikleri de bilinmektedir (Armağan, 2008: 85).

Türkiye'de konar-göçerliğin son temsilcileri arasında yer alan Sarıkeçililer, düşük rakımlı kışlaklar ile yüksek rakımlı yaylalar arasında hareket ederek, dikey göç hareketini benimsemişlerdir; ancak Sarıkeçililer sadece çobanlık değil, aynı zamanda göç esnasında kullandıkları develer ve diğer yük hayvanları sayesinde nakliyecilik, kervan ve bölük izciliği de yapmışlardır (Aydın ve Yağcı, 2013: 60, 72; Tuztaş, 2014). Benzer şekilde, birkaç kuşak öncesine kadar Antalya'nın Korkuteli ve Döşemealtı bölgeleri ile Anamas Dağı ve Seydişehir'in dağlık bölgeleri arasında konar-göçer olarak yaşadıkları, sahip oldukları yük hayvanları 
nedeniyle askeri seferlerde görevlendirildikleri, hatta tuz ticareti ağının içinde yer aldıkları, Kızılcıklıların anlatımları arasındadır.

Konar-göçerlerin yerleşik hale gelmesi 17. yüzyılda Osmanlı coğrafyasında başlayıp Cumhuriyet Türkiye'sinin ikinci çeyreğine kadar süregelen karmaşık bir olgudur. Özellikle 16. yüzyılın sonlarından itibaren bir yüzyıl boyunca yaşadığı ekonomik ve toplumsal sorunlar nedeniyle benimsediği iskân siyaseti ile arazinin kullanım biçimini, üretim araçlarını ve insan kaynağını yeniden örgütleme yoluna giden Osmanlı Devleti, bazen teşvikle bazen zor kullanarak konar-göçerleri zorunlu iskâna tabi tutmuş, böylece hem boş veya terk edilmiş arazileri tarıma açmaya hem araziyi kayıt altına almaya hem de çiftçilerin ekili topraklarını çiğnemekten, mahsullerini ve hayvanlarını gasp etmekten kaçınmayan insan popülasyonunu kontrol etmeye çalışmıştır (Orhonlu, 1987: 27-45). ${ }^{5}$ İskân siyaseti daha sonraki yüzyıllarda da devam etmiş, 1838 ve 1856 yıllarında yapılan kadastro çalışmaları, 1858 tarihli Arazi Kanunnamesi ile özel mülkiyete imkân verecek şekilde toprak rejiminin yeniden şekillendirilmesi, 1871 tarihli Vilayet Nizamnamesi ile idari teşkilatın vilayet-kaza-nahiye-köy olarak tesis edilmesi, göçebe-çobanların göç hareketine ciddi bir müdahaleyi beraberinde getirmiştir (Aydın ve Yağcı, 2013: 61-62). Bir başka deyişle, yaylak-kışlak olarak kullanılan araziler idari teşkilatların sınırlarına dâhil edildiğinden, bunun konar-göçerler açısından bazı sonuçları olmuştur. Bunlardan birisi, klasik Osmanlı düzeninde konar-göçer gruplar için sınırların belirlenip tahrir defterine kayıt edilerek yurt (yaylak ve kışlak) olarak tahsis edilen çayır ve otlakların (Armağan, 2008:74) artık köy merası statüsüne dönüşmüş olmasıdır. Dolayısıyla bu meralık alanlar sadece köyün ihtiyaç fazlası olduğu durumlarda kiralama yoluyla kullanılabilmiştir (Aydın ve Yağc1, 2013:62). Vilayet nizamnamesinin yol açtığı bu durum köylülerle konar-göçerler arasında geçen sonu gelmez çatışma-çekişmelere yeni bir boyut katmıştır. Orhonlu (1987:37) bu çatışmalı ilişkiyi çoban ile saban arasındaki bir mücadele olarak tarif

${ }^{5}$ Osmanlı İmparatorluğu'nun üretim ve vergilendirme süreçleriyle ilgili 16. yüzyıldan itibaren başlayan yapısal değişiminin dünya ekonomisiyle ilişkisi için bkz. Kasaba 1993.

$\mathrm{SAD} / \mathrm{JSR}$

Cilt / Volume 20 Say / Number 1 
etmektedir. Görüşmecilerden birisi de benzer bir ifade kullanmıştır: 'Tarımla uğraşan ile çobanlık birbirine zarar verir. Bu ikisi birbirine uymaz.' Çünkü bu iki geçim örüntüsünün üretim biçimlerinin, araziyi kullanma stratejilerinin, vb birbirinden farklılığı, aynı alanı kullanım amaçları bakımından ciddi bir rekabeti beraberinde getirmektedir.

Ayrıca, 19. yüzyıl sonlarıyla 20. yüzyıl başlarında yeni demiryolu hatlarının açılmasıyla gerçekleşen yoğun tarımsal kalkınma girişimlerinin yol açtığı yapısal dönüşüm, Yörükleri iskâna zorlayan bir faktör olarak ortaya çıkmıştır. Kışlaklarındaki sulak alanların devlet desteğiyle kurutularak yeni köy yerleşimlerine açılması, göç hareketini neredeyse imkânsız hale getirmiştir (Bates, 2009:220). Kızılcık köyü sakinlerinin yerleşik yaşama geçişleri de bu tarihlere rastlamaktadır.

Yaşlı bir görüşmecinin anlatımına göre, '1308'lerde [1890'lar] ... O Yörügün içinde muhtar' olan dedesi kendilerine ‘bir yer tutmak’ için ‘63 hane’ ile Kızılcık mıntıkasına gelmiş. Sarıkeçili Kelceler sülalesinin bu mıntıkaya gelerek yerleşik hayata geçtiği tarih, Böcüzâde Süleyman Sami’nin 1915 yılında tamamladığı Isparta Tarihi kitabında düşülen kayıt ile aşağı yukarı örtüşmektedir: "Kızılköy mevkiine otuz sene evvel bu havalide sayfen hayme-nişîn bulunan [yazın çadırda yaşayan] Sarıkeçili aşiretinden yirmi-otuz kadar hane iskân edilmiştir” (2012:54). Bazı görüşmecilere göre, yer seçiminde yörede bir su kaynağının olması önemli rol oynamış. Bu seçime şimdiki muhtar biraz da alayla karışık hayıflanıyor, 'Eski Yörük akıllı değil. Derenin içine konmuş, Gönen'in tarlasına konmamış’ diyerek. Bu bakış açısı, 'Ben köstebek değilim, toprak dürtecek' veya 'ne edeceğim tarlayı, ekmeği kara erkeçten [erkek keçi] yiyorum' türünden ifadelerle yerleşikliği küçümseyen, zamanında ovaya yerleşmeyen aile büyükleri karşısında yeni kuşakların mekân algısındaki değişimi göstermesi bakımından anlamlıdır.

Kızılcıklı Sarıkeçililer yerleşik hayata geçmekle birlikte, bu durum onların sürü ekonomisinden vazgeçtikleri anlamına gelmemektedir. Yeni yaşam alanlarında yapılaşmış bir faaliyet olarak sürü hayvanlarına dayalı üretim biçimlerini devam ettirmişler, ancak bu üretim faaliyetine ket vurucu bir başka

$\mathrm{SAD} / \mathrm{JSR}$

Cilt / Volume 20 Sayı / Number 1 
sorunla karşılaşmışlardır. Şöyle ki; 1937 yılında yasalaşarak devlet ormancılığı dönemini başlatan 3116 sayı1ı Orman Kanunu, özellikle kı1 keçilerin ormanlık alanlara sokulmasını yasakladığından (Gümüş, 2014), yaylacılık faaliyetlerini sürdürmeye gayret eden son konar-göçerler üzerinde derin bir etki yaratmıştır. Bazin'in araştırması Sarıkeçililerin yaylacılık/ göçerlik faaliyetlerinden nasıl geri çekildiklerini ortaya koymaktadır:

Mevcut ormanların çevrelerinin korunması ve ormanla ilgili ağaçlandırma işlemlerinin artması sonundaki baskı altında, uygun otlaklar yavaş yavaş azalmaktadır. Karaman kuzeyinde volkanik bir masif olan Karadağ, yirmi yıl kadar önce, Silifke batısında kışlayan Sarıkeçili aşiretinin tamamını topluyordu. Karadağ giderek kapanmış ve 1985 yılında son ziyaret eden aileler onu terk etmek zorunda kalmışlardır (Bazin, 1993:339).

Dolayısıyla Orman Kanununun Kızılcıklıları çıkmaza sokarak, başka köylere ait meralık arazileri kiralamaya yöneltmesi görüşmecilerin ortaklaştığı bir sorun olarak dile getirilmiştir. Kiralamanın getirdiği maddi külfeti minimize etmek için geliştirilen stratejilerin ilginç bir örneği, köyde evi olsa da çobanlığı ve çadır yaşamını büyük oranda sürdüren bazı Kızılcıklılara aittir. Isparta yöresinde meralık alanı kiralama bedelinin yerli-yabancı ayrımına göre farklılık göstermesi, bir görüşmecinin nüfus kütüğünü kiraladığı meralık alanın bağlı olduğu ilçeye aldırmasına yol açmış ve böylece kiralama bedelinin büyük oranda düşmesini sağlamış: "O zamanlar yerli-yabancı şeyi vardı. Yerliye bacakbaşı 50 kuruşsa, yabancıya 150 kuruşa veriyordu."

Günümüzde Kızılcıklılar, arazi satın alarak, devletten arazi kiralayarak (ecr-i misil) ekonomik sermayesini artırmaya gayret etmekle birlikte, ekonomik faaliyetlerin merkezinde hâlâ hayvan yetiştiriciliği vardır. Yerleşik hayata geçiş sonrasında geleneksel yaylacılık pratiklerini sürdürmekle birlikte, köy içinde gerçekleştirdikleri sığır yetiştiriciliği ve yeni besi teknolojileri ile hayvan üretimine dayalı faaliyetleri çeşitlendirdikleri gözlenmiştir. Neredeyse bir yüzyıllık yerleşiklik/ köylülük pratiğine rağmen, Kızılcıklı 
kendini Gönenli bir çiftçi olarak değil, Sarıkeçili bir Çoban, bir Yörük olarak görmektedir. Hatta Sarıkeçili Yörük olmayı, ‘asalet sahibi olmak', ‘köklü sülaleden gelmek’ olarak değerlendirerek, simgesel sermayenin önemini vurgulamaktadırlar. Ne var ki sahip oldukları bu simgesel-kültürel sermaye sosyal sermayelerini geliştirmelerine ket vurucu bir işlev görmektedir. Görüşmecilerden biri çoban olarak kendisine kız verilmediğini, mülkiyetini edindiği arazisi olsa da maaşlı bir çalışan olarak görünmek için bir devlet kurumunda çalıştığını söylemiştir. Sahip olduğu ekonomik sermayesi içinde aldığı ücreti küçümsese de sosyal sermayesini artırmak için çoban olarak değil, memur olarak algılanmanın yararını seçmiştir. Bazin'in de benzer gözlemleri vardır: “[K]öylüler, Sarıkeçili aşiretine ayrı bir grup gibi bakıyor ve onlarla ilişkisini oldukça alt düzeyde tutuyorlar. Böyle bir dışlamaya doğal cevap, kendi içlerinde tutkun olmayı güçlendirmektedir” (1993:342). Dolayısıyla Kızılcıklıların başka grupların küçümsediği Çoban/ Yörük kimliğine sıkı sıkıya sahip çıktıkları ve fakat yeni kuşakların eğitim, meslek edinme yoluyla yeni simgesel ve sosyal sermaye türlerini geliştirmeye çalıştıkları gözlenmektedir.

Bazin'in dediği grup-içine karşı hissedilen "tutkun olma" duygusu, görüşmecilerin ifade ettiği 'dayanışmacı' tutum, Kızılcıklıların hem sermaye türlerini hem de toplumsal uzamdaki konumlarını şekillendirmekte, toplumsal yapının yeniden üretilmesindeki stratejilerin geliştirilmesinde rol oynamaktadır. Örneğin köy sınırları içindeki arazinin satış yoluyla el değiştirmesinin kabul görmediği bir mülkiyet stratejisiyle, köye bir başka toplumsal gruptan bireylerin gelip yerleşmesini engellemeye çalışmaktadırlar. Bu eğilimi yansıtan bir ifade Gönenli bir görüşmeciye aittir: 'Onlar alırlar, satmazlar.' Özellikle büyük sermaye birikimi ile gelip, arazi almak ve üzerinde hayvancılık yapmak isteyenlere karşı çekinceleri olduğu gözlenmiştir. Dışgruptan gelen bu türden talepler kendi ekonomik sermayesine, sürü yetiştiriciliğine dayalı üretim biçimine karşı bir tehdit olarak algılanmaktadır. Dolayısıyla ortak deneyimlere ve akrabalık ilişkilerine dayalı olarak yapılaşmış bir alanda, sahip oldukları sermaye türlerini dışarıdan olanlar ile rekabete, çatışmaya girmeyecek şekilde korumaya çalıştıkları söylenebilir. Öyle ki, 'yazlamak' için arazi satın alan birkaç yabancı ailenin varlığ1 veya Kızılcık’tan göçmüş kendi köylüsünün dönüp tekrar yerleşmesi bile bu dayanışma duygusunun

$\mathrm{SAD} / \mathrm{JSR}$

Cilt / Volume 20 Say / Number 1 
zedelenmesine yol açtığı görüşmecilerin anlatımlarından anlaşılmaktadır: 'Eskiden dayanışma iyiydi ama şimdi yok o... Şimdi bizim buralara yabandan da gelen oldu... Burada kurulmaz ki birlik, nasıl kuracaksın.'

Köy-dışı toplumsal grupları imleyen ‘yaban' metaforu aslında köyün şimdiki sakinleri ile dışarıdan gelen eski Kızılcıklıların veya yabancıların sahip olduğu sermaye türü ve hacmindeki farklılığa işaret etmektedir. Örneğin, yazın köyde, kışın Gönen merkezde yaşayan Kızılcıklı bir görüşmecinin çocukluktan itibaren kısmen köy-dışı bir ortamda yetişmesi, kısmen örgün eğitim süreçlerinden geçmesi, kısmen farklı alan mücadelelerinin gerçekleştiği kurumsal yapılarda çalışması, onun ‘yabandan gelen’ olarak algılanmasına yol açacak şekilde görece bir toplumsal uzam farkı yarattığı söylenebilir. Ancak bu farkın alan mücadelesine dökülmeyişinin nedeni, hem akrabalık ilişkilerinin bu gerilimi emme kapasitesinde hem de yabandan gelenlerin/ yabancıların köydeki takipçi konumunda aranabilir.

Okullar, Bourdieu’ya göre, kültürel sermayenin çeşitli biçimlerinin üretimi, aktarımı ve biriktirilmesi açısından temel kurumsal koşulları sağlar (Swartz, 1997:189). Bir başka deyişle, okullar toplumsal tabakalaşmanın veya farklılıkların üretilmesindeki başlıca kurumsal yapılardır. Gönen İlçe Milli Eğitim Müdürlüğü’nden alınan verilere göre, 1949 yılında üç derslikli olarak açılan Kızılcık ilkokulu 13 erkek, 5 kız öğrenci ile eğitime başlamıştır. ${ }^{6}$ Ancak görüşmecinin hayat öyküsünden anlaşıldığı üzere, 3. sınıftan sonraki basamakları Gönen veya Isparta merkez okullarında tamamlamak gerekiyordu ve okullaşma süreçlerine katılım o günün şartlarında ancak ailenin olanakları dâhilinde mümkündü. Kızılcıklıların hiçbir koşulda vazgeçmedikleri yaylacılık faaliyetleri göz önüne alındığında, diğer iki köye kıyasla, bu köyde ilkokul sonrası okullaşmanın uzunca bir süre çok düşük düzeyde kalması şaşırtıcı değildir. Özellikle, sürü yetiştiriciliği ve domestik işlerde kız çocuklarına düşen görevler nedeniyle erkek çocuklarına göre onların

${ }^{6}$ Üç köydeki okullarla ilgili veriler, Gönen İlçe Milli Eğitim Müdürlüğü ile yapılan görüşmeye dayanmaktadır.

$\mathrm{SAD} / \mathrm{JSR}$

Cilt / Volume 20 Say1 / Number 1 
örgün eğitim olanaklarından yakın zamana kadar yararlanamadıkları, görüşülen orta yaş üstü kadınların anlatımlarında yer almaktadır.

Yukarıdaki örnek üzerinden devam edersek, görüşmecinin kök ailesinin ilçe merkezine taşınarak örgün eğitimden yararlanmasını sağlayacak bir stratejiyi benimsemesi, onun köydekilerden kısmen farklı sermaye tür ve hacmine sahip olmasında önemli bir rol oynadığı söylenebilir. Ancak orta seviyede bir örgün eğitimle farklı alanların mücadelesi için yeterli bir kültürel sermaye birikimini gerçekleştirememek, onun emeklilik sonrası köyüne dönüp tarımsal faaliyetlere başlamasını, hayvan besiciliğini yaz aylarında köyünde, kış aylarında Gönen ilçesindeki mandırasında yapmasını anlaşılır kılmaktadır. Ekonomik ve sosyal sermayesini kurumsal ilişkilerle genişletmiş olsa da, görüşmecinin seçtiği eylem hattı kendi kök ailesinin yapılaşmış habitusudur. Bununla birlikte, kendisi ile çocukları arasında bir kopuştan söz edilebilir, çünkü üçüncü kuşak köyün dışındaki alanların birer aktörüdürler artık. Bu kopuşu görüşmecinin sözlerinden kolaylıkla çıkarsayabiliriz: ‘Isparta'da, Bodrum’da gezme-tozma iyi; burda [köy] ne etsem, gelmiyorlar.' Buna benzer ifadeler başka görüşmecilerinin de dilindedir: 'Çocuklar artık çobanlık yapmak istemiyor; oğlan istese gelin istemiyor. Sosyete yaşantısı istiyorlar.'

Kısaca, Kızılcıklıların ortak deneyimlerinden kaynaklanan eylem hatları, içselleştirip sahiplendikleri Yörük kimliği, akrabalar arası gösterdikleri dayanışmacı tutum, vb nedenlerle kendi aralarında açık bir alan mücadelesinin olmadığı söylenebilir. Bir vakitler başka bir yere gidip dönmüş olanların 'yabandan gelenler' olarak nitelendirilmesi ise, köy-içinde toplumsal bir uzam farkının olduğunu ortaya koymaktadır. Bununla birlikte, toprak mülkiyeti ve sürü ekonomisine yönelik olarak verdikleri alan mücadelesinin yabandan gelen kendi soy grubundan ziyade yabancıya karşı yapıldığ1 ileri sürülebilir. Çünkü konar-göçerlik yaşam biçiminin grup üyesinden talep ettiği iç-gruba yönelik dayanışmacı tutumun ekonomik sermaye türlerinin çeşitlendirebildiği, aşirete dayalı örgütlenmenin zayıfladığı köylülük yaşantısında geçerliliğini yavaş yavaş 
kaybetmesi, orta yaş ve üstü Kızılcıklıların kendilerini dış-grup tehdidine açık hissetmelerine yol açmaktadır.

\section{Baladız (Gümüşgün) Köyü: 'Baladız'ın bir geçmişi var...'}

Baladızlıların ortaklaştığı, yapılaştırıcı bir mekanizma içinde kazandığı kültürel kimliği, AlevilikBektaşiliktir. Aşure günleri gibi tüm köyün el birliğiyle gerçekleştirdiği etkinliklerle, çeşitli dini ritüellerle, sahip olduğu yatır ve türbeleriyle kültürel kimliği şekillenmekte ve habitusunun asli unsuru olmaktadır. Ancak bu köyde yaşayanların, kendilerini Gümüşgünlü (1961'de verilen isim) olarak değil de 'Baladızlı' olarak tanımlamaları, kültürel kimliklerindeki bir başka katmana işaret etmektedir.

Köy adının taşıdığı simgesel sermaye değeri, geçen yüzyılın ortalarında yaşanmış (1946) bir olaya dayanmaktadır. O tarihlerde çiftlik statüsünde olan Baladız'da, 'çiftlik ağası' Abdullah Demiralay’ın köylülerce öldürülmesine ilişkin dramatik olayın 'hakkını arama' olarak kodlandığı ve ilk kuşak aktörlerin aktarımlarıyla ve Ruhi Su'nun dizeleri ve bestesiyle 'Baladız Destanı'na dönüşerek, toplumsal bellekte günümüze kadar yaşatıldığı görülmektedir. Süleyman Erdal'ın (2011) o dönemde yaşanan olayları özetlediği, Yaşar Kemal, Fakir Baykurt, Elia Kazan'ın 'köyün hikayesi'nin peşine düşerek, Baladız'a geldiğini anlattığı kitapçığı; 'Baladız Destanı'nın tabelaya yazdırılarak köy kahvesine astırılması; yakın zamana kadar köydeki bir türbenin camına Ruhi Su'nun şiiriyle birlikte olayla ilgili gazete haberlerinin de yapıştırılmış olması, toplumsal belleğin açık görünümleridir. Yerel yönetimlerle ilgili yeni yasal düzenlemelerin bir sonucu olarak, halk oylamasıyla köyün mahalle statüsüne geçmesini ve destanı tabelaya yazdıranın Güneykent Belediyesi olmasını onaylamayan bir görüşmeci, simgesel sermaye temelli çatışma ve mücadeleyi şu ifadelerle ortaya koymaktadır: ‘Köyün destanı var yıllardır, kalkıp da başka biri yazdırdı... Güneykent Belediyesi oldu yaptıran. Eskiden Baladız'dı. Köyün bir geçmişi vardı, ben kabullenemiyorum.'

Baladız köyünün ismi, ilk defa Osmanlı dönemine ait 1500/01 tarihli 30 numaralı Defter-i Hakani kaydında karşımıza çıkmaktadır. Buna göre, "Baradiz” 34 haneli bir köydür (Dağlığlu, 1941: 1127). Arıkan ise,

$\mathrm{SAD} / \mathrm{JSR}$

Cilt / Volume 20 Sayı / Number 1 
“Barduz"un 16. yüzyıla ait müsellem defterlerinde İrle'ye (Yeşilova, Burdur) bağlı bir nahiye olarak gösterildiğini; bir tuzlaya sahip olduğunu belirtmektedir (1988:37, 113). Baladız isminin geçmişteki Baradiz veya Barduz'dan türediği varsayılabilir. Bununla birlikte, aralarında Baladız ve İğdecik köylerinin de olduğu Hamit sancağındaki birçok köyün 16. yüzyıl sonlarında baş gösteren ve bir yüzyıl kadar devam eden Celali isyanları ve zaman zaman veba gibi hastalıklar nedeniyle boşaldığı ve yeniden inşa edildiği kaynaklarda yer almaktadır (Böcüzade, 2012: 54).

Baladız'ın ne kadar süre boş kaldığı tam olarak bilinmemesine rağmen, Fandas [Koçtepe], Gölbaşı ve Senirce çiftlikleriyle birlikte bu çiftliğin de Hamit sancağı mutasarrıfı Çelik Mehmet Paşa'ya ait çiftliklerden ayrılarak, Yılanlığulları'ndan iki erkek kardeşe, Abdullah Paşa ve Tahir Paşa'ya satıldıktan sonra hayatiyet kazanmıştır (Böcüzade, 2012: 54). 18. yüzyılın ikinci yarısından 20. yüzyıla kadar mütesellim, vb. olarak Hamit sancağında yürüttükleri idari, mali ve askeri görevleriyle yerel bir hanedanlığa dönüşen Yılanlıŏulları, malikâne sisteminin ortaya çıkardığı toprak sahibi sınıfın Isparta' daki bir örneğidir (Köse, 1935:266). ${ }^{7}$ Daha sonra Demiralay soyadını alacak olan Tahir Paşa'nın oğulları ve torunları, 1960'lara kadar Isparta ilinin siyasi, toplumsal ve ekonomik hayatında etkin bir rol oynamışlardır. ${ }^{8}$ Demiralay ailesinin bazı üyeleriyle yapılan görüşmelere göre, ekonomik sermayelerinin birer tezahürü olarak çiftliklerindeki ve kent içindeki konakları, Isparta siyasetinde ve sosyal yaşamında birer çekim merkezi olmuştur. Örneğin, İsmet İnönü, Adnan Menderes gibi yüksek siyaset sınıfından bazı kişiler, bu konakların misafirleri arasında yer almışlardır.

\footnotetext{
${ }^{7}$ Malikâne sistemine bağlı olarak ortaya çıkan çiftlik sisteminin detaylı tartışması için bkz. İnalcık, 1998; Akdă̆, 1963.

${ }^{8}$ Yılanlığulları gibi, klasik dönem sonrası Osmanlı yönetim sisteminden köken alan ve içinde bulunduğu coğrafyada siyaseten bir erk konumunda olan aileler/ sülaleler, başka bölgelerde de karşımıza çıkmaktadır. Örneğin, Trabzon'un Of ilçesinin yerel tarihinde etkin olmuş büyük ailelerle ilgili antropolojik bir analiz için bkz. Meeker, 2005.
}

$\mathrm{SAD} / \mathrm{JSR}$

Cilt / Volume 20 Sayı / Number 1 
Baladız sakinlerinin ise, köyün yerleşim alanı da dâhil olmak üzere Abdullah Paşa'nın mülkiyetine ait bu çiftliğe ortakçı/kiracı olarak gelmiş, birbiriyle köklü akrabalık ilişkisi bulunmayan aileler olduğu düşünülebilir. 1970’lerde Gönen Belediye Başkanlığı görevinde bulunmuş yaşlı bir görüşmecinin Baladızlılar hakkındaki ifadesi de bu yöndedir: 'Dışarıdan gelenler[di], marabaydı onlar.'

Bu köyün özgül tarihi üzerinden toprak mülkiyetinin değişimine bakıldığında, Keyder'in (1985:92-94) çalışması açıklayıcı bir çerçeve sunmaktadır. Ona göre, Osmanlı devleti kuruluştan itibaren köylülerin serfleşmesini önleyici toprak tasarrufu modellerine başvurmuş olmasına rağmen, özgür köylülük ”yerel devlet görevlilerinin baskısına sık sık boyun eğmek" zorunda kalmıştır. Bunu engellemek amacıyla 19. yüzyılın ilk yarısından itibaren Osmanlı idaresini yeniden merkezileştirme yoluyla toprağa dayalı siyasi gücün sınırlandırılmaya çalışıldığını ve böylece 1830’larda malikânelerin zorla parçalandığını, 1858 Arazi Kanunnamesi yoluyla çiftliklerin kurulmasının zorlaştırıldığını belirtmektedir. Keyder (1985), ayrıca, para ekonomisinin ve tefeciliğin köylere girdikten sonra köylülerin ortakçılık seçeneğiyle karşı karşıya geldiğini ve bu yolla büyük toprak sahiplerinin üretim ölçeğini büyütebildiğini ifade etmektedir. Yerel düzeyde, Çelik Paşa malikânesinden bazı çiftliklerin neden ayrılarak satılma ihtiyacı hissedildiği ve bu yazıya konu olan çiftlikte köylülerin neden ortakçılık yapmak zorunda kaldığı meselesi bu yapısal süreçlerle ilişkili olduğu düşünülebilir.

Köylünün ortakçılıktan bir türlü kurtulamaması, Keyder ve Pamuk’a göre, ekilebilir toprakların azlığından veya bu topraklara köylünün erişiminin olmamasından dolayı değil, "ağanın... çeki hayvanlarını tekelinde bulundurmasından kaynaklanmaktaydı... Köylü bir çift öküz ve bir saban alacak kadar para biriktiremediği için ortakçı ve kiracı olarak sömürülmek zorunda kalıyordu” (1984-85:60-61). Baladızlı yaşlı görüşmeciler bu konuyla ilgili olarak, her ortakçının çeki hayvanlarına ve ağaç saban, pulluk gibi tarımsal aletlere sahip olduğunu; ağanın öküzü olan ortakçılara kıraç arazileri, genç ve sıhhatli atları olan ortakçılara verimli arazileri verdiğini, bu nedenle zayıf çiftçinin her zaman zayıf kaldığını belirtmişlerdir. Dediklerine göre, 
onlar 'ne aç kalır ne tok olurdu'. Ayrıca harman zamanı geldiğinde ağanın birtakım uygulamalarının ortakçı/ kiracı ailelerin aleyhine işlediği, görüşmecilerin anlatımları arasındadır. Geleneksel yöntemle hasat edilen ürün (buğday/ arpa) sap ve samanından ayrılırken, başak ve tanelerden ağır/ iri olanlarının 'rüzgârın geldiği tarafta', hafif ve cansız olanların ‘yel önü’ denilen diğer tarafta toplandığını; bölüşürken ağanın kendi payını ve tohumluğu 'yelin estiği, iri taneli yerden' aldığını anlatmışlardır. Dolayısıyla çiftlik ağasının sosyal ve ekonomik sermayesine dayanan gücünün sürekliliği, işletmenin verimliliğini artırmak ve kendi kârını azamileştirmek üzerine kurulu iş planından ve ürünü paylaşım stratejisinden kaynaklandığı görülmektedir. Diğer yandan, ortakçının sahip olduğu hayvanın niteliğine, ailesinde genç erkek olup olmadığına göre kimin hangi araziyi ekeceğini belirlemesi, ortakçılar arasında nispi bir tabakalaşmaya yol açmış olduğu söylenebilir.

Ne var ki, Baladızlı ortakçı/ kiracılar gerekli üretim araçlarına sahip oldukları halde bu kısır döngüden çıkamamışlardır. Bunun nedeni, Isparta ve Burdur yöresinde (Hamit sancağı) birçok köyün çeşitli ailelerin özel mülkiyetinde birer çiftlik olarak işletilmesinde bulunabilir (Böcüzade, 2012:488). Bununla birlikte, 20. yüzyılın başlarında Baladızlı birkaç ailenin Fandas (Koçtepe), Kılıç gibi çevre köylere gidip tarla alma girişimleri, o köyün yerleşik bireyleri tarafından engellendiği belirtilmiştir. Bir görüşmecinin sözleriyle, 'Tarla vermezler. Biz bile bir yabancının tarla almasını istemeyiz. Makbul olsa kendi köyünde dururdu, derler'. Dolayısıyla bu meselenin yanıtı toprak mülkiyeti, üretim araçları gibi kaynakların varlığı veya yokluğunun yanı sıra yerleşimcilerin bir toplumsal-coğrafi habitatı koruma stratejilerinde de aranabilir. Kısaca, Baladızlı ortakçı/kiracıların kendileri adına üretim yapmak için gidebilecekleri pek fazla alan yoktu; ancak ilk fırsat karşılarına çıktığında, aşağıda görüleceği gibi, kendileri adına stratejik bir adım atabilmişlerdir.

Demokrat Parti (DP) Isparta il başkanı Abdullah Demiralay'ın öldürülmesine (1946) yol açan olayın köylülerle arasındaki borçlu-alacaklı ilişkisinden kaynaklandığı bilinmektedir. Dönemin Cumhuriyet 
Gazetesi'ndeki (Isparta Cinayeti Hakkında, 20.8.1946) bir haberde, 1941 yılında Demiralay'ın annesi ve kız kardeşinin arazilerini (6500 dönüm) köylülerden 42 kişiye sattığı; 1944 yılında karısı ve oğlunun “uhdesindeki” arazinin (6000 dönüm) "Tarım Bakanlığının delâlet ve tavassutu” ile ilk gruptan ayrı 28 kişiye satıldığı; annesi ve kız kardeşine ait arazileri satıştan evvel ilk gruptaki 42 kişiye beş yıllığına kiraya vermiş olduğu, ancak kira bedelinin ödenmesi konusundaki anlaşmazlık sonucu onları mahkemeye verdiği; söz konusu olayın, icra işlemleri esnasında gerçekleştiği belirtilmektedir. Baladızlı yaşlı görüşmecilere göre, kira bedelini ödedikleri halde çiftlik ağasının 'sahte' senetlere dayanarak kendilerini icraya vermesinin nedeni, annesinden satın aldıkları 'bütün tarlaları bedava almak istemesidir.' Bir başka deyişle, 'Beni anamın malından mahrum ediyorsunuz' diyerek, 'davarlarını, buğdaydan/ arpadan artırdıklarını, vb satıp, [parasını] taksit taksit ödedikleri' araziyi icra yoluyla kendi mülkiyetine geçirmek istemiştir. Bazı görüşmeciler Demiralay'ın öldürülmesini onaylamasa da, bir görüşmeciye göre, bu olay, 'bıçak kemiğe dayandığından' olmuştur.

Isparta yöresinde tanınmış bir ailenin arazilerini satma yönündeki kararının 1930-40'lı yıllarda tarımsal politikalar bağlamında büyük çalkantılara yol açan 4753 sayılı Çiftçiyi Topraklandırma Kanunu (ÇTK) ile yakından ilgili olduğu ileri sürülebilir. ${ }^{9}$ Şöyle ki; 1927 yılında yapılan ilk tarım sayımına göre, Türkiye'nin doğu ve güneydoğusu hariç, mülk topraklarının \%97,7'si 125 hektardan küçüktü ve çiftçi ailesi başına 25 dönüm arazi düşmekteydi; bu nedenle, 1927 ve 1929 yılında topraksız köylüyü topraklandırma kanunu çıkarılarak devlete ait miri topraklardan 11 bin hektar kadar toprak köylüye dağıtılmıştır (Kepenek ve Yentürk, 2000:70, 42). 1933-35 yılları arasında köylüye toprak dağıtılması meselesi, “tapusuz toprakların çiftlik ağalarının elinden alınıp, topraksız köylüye dağıtılması” (Keyder ve Pamuk, 1984-85:53) yönünde

\footnotetext{
${ }^{9}$ Keyder ve Pamuk (1984-85:62), 1929-1945 yılları arasında siyasi arenada yakıcı bir konu olan topraksız köylüyü topraklandırarak pazarlanabilir ürün miktarını artırma iddiasının geçerliliğini sorgulamakta ve 1930-40'lardaki tarım teknolojilerini ve ürünün pazarlanma koşullarını daha iyi anladığımız takdirde ÇTK'ya yeni yorum getirme imkânı doğacağını ileri sürmektedir. Konuyla ilgili diğer tartışmalar için bkz. Barkan, 1980; Karaömeroğlu, 1998; Özer, 2013.
}

$\mathrm{SAD} / \mathrm{JSR}$

Cilt / Volume 20 Say / Number 1 
yasa hazırlıkları noktasına gelince, tartışmalar alevlenir. CHP’nin büyük toprak sahibi olan kanadı, özel mülkiyet ilkelerine aykırı olduğu ve verimliliği ihmal ettiği düşünceleriyle tasarıya şiddetle karşı çıksa da, topraksız veya az topraklı köylülere toprak vermek, üretim araçları için kredi sağlamak, toprakların belirli bir büyüklükte kalmasını ve kullanımının sürekliliğini garanti altına almak olan ÇTK, 1945 yılında yasalaşır (Birtek ve Keyder, 1976:38; Karaömeroğlu, 1998). Ancak “kiracılar tarafından işlenen 50 dönüm üzerindeki toprakların kamulaştırılıp yeniden dağıtılabileceği hükmü”nü içeren tartışmalı 17. maddesi pek fazla hayata geçirilemeden 1950 y1lında iptal edilir (Balta, 2002: 287). ${ }^{10}$

Bu süreçte, söz konusu kanuna ilişkin tartışmaların hem siyasal arenada hem de yerel düzeyde bazı etkileri olur: Demiralay ailesinden bir görüşmeciye göre, 'büyük toprakların dağıtılacă̆g' yönündeki haberlerle ‘toprak reformu propagandası' yapılmış; 'İsmet Paşa toprak reformu üzerinde 1srar edince, dört kişi [CHP'den] istifa edip DP'yi kurmuştur.' Keyder ve Pamuk (1984-85:54) da DP'nin oluşumunu sağlayıc1 etkenlerden biri olarak toprak reformu tartışmalarını göstermektedir. Dolayısıyla toprağın yeniden dağıtımı yönündeki girişimler yeni bir partinin kuruluşunda belirli bir rol oynarken, Baladız çiftliğinin sahibi de arazileri üzerinde bazı tasarruflarda bulunur. Afife Hanım, 1930'ların ikinci yarısında arazilerinin bir kısmını önce birinci derece mirasçılarına devreder ve daha sonra kökten bir karar vererek, kızıyla birlikte arazilerini satmak yönünde bir tercih yapar. Bu satış kararının nedeni, Baladızlı görüşmecilere göre, çiftlik ağasının annesine ve kız kardeşine kıraç arazileri vermesi veya onlara gelirden pek fazla pay vermemesi gibi gerekçelerdir; diğer yandan, Ispartalı eşraftan bazı görüşmeciler açısından, ÇTK kanununun sonuçlarından etkilenmemek içindir. 1941 yılındaki ilk parti satışın bireysel gerekçesi ne olursa olsun, toplumsal düzlemde, köylülerin daha fazla tarımsal arazi elde etme yönünde beklentilerinin arttığı; Gönenli bir görüşmecinin ifadesiyle, 'toprak reformu yapılacak diye vatandaşın kendisinin taksim yapmaya

${ }^{10}$ ÇTK çerçevesinde 1947-72 yılları arasında 22 milyon dönümden fazla arazi topraksız ve az topraklı köylülere dağıtılır ve bunların sadece binde ikisi (54bin dönüm) şahıslara ait arazilerdir; geri kalanı devlet arazisidir (Keyder ve Pamuk, 1984-1985:54).

$\mathrm{SAD} / \mathrm{JSR}$

Cilt / Volume 20 Say / Number 1 
başladığı’ görülür. Bourdieucü anlamda, Baladızlı köylülerin alan mücadelesini politik düzleme taşıyarak kazanmaya giriştikleri söylenebilir. Bunu gösteren bir anlatının Baladız’ın sözlü tarihinde önemli bir yeri vardir:

İsmet İnönü trenle geldi [1943], burada [Baladız İstasyonu'nda trende] yattı bir gece. Çocuğudum o zaman, bu çiftlik dağılmadan. Burada bizim ihtiyar bir kadın vardı. Gitti İnönü’nün karşısına çıtı. “Paşam bizim ölünce yatacak yerimiz [mezarımız], toprağımız yok” dedi.

Bu olayın ardından, İnönü, Demiralay’1 Ankara’ya çağırarak bir miktar arazisinin kamulaştırılması yönünde girişimde bulunur. İnönü ile Demiralay arasındaki görüşmenin nasıl gerçekliği konusunda bir belgeye sahip olmamakla birlikte, Baladızlılar arasındaki yaygın kanıya göre, İnönü’nün bu mücadelede 'biraz faydası' olmuştur. Böylece, 1941 yılındaki ilk satıştan toprak satın almamış olan Baladızlı 28 kişi, 1944 yılında kamulaştırılan araziden banka kredisi yoluyla 'parası kadar' hisse satın alır. İlk satıştan hisse alan bir görüşmecinin değerlenmesi şu yöndedir: 'Bizden önce almasalar da onlar, bizden kolay aldılar. Parasız, yani parayı devlet ödedi sonra onlar rahatça [bankaya] ödediler.'

ÇTK’ya ilişkin tartışmalar, Demiralay’ın öldürülmesi gibi olaylar Demiralay ailesi üzerinde sahip oldukları diğer çiftliklerin satışı yönünde bir baskı oluşturur ve çiftlik sistemi büyük oranda ortadan kalkar. Baladızlılar, ortakçılıktan/ kiracılıktan çıkıp, üreticisi oldukları toprağın mülkiyetini elde etmelerini 'toprak reformu'na bağlamaktadırlar; hatta Türkiye'deki ilk toprak reformunun kendi köylerinde gerçekleşmiş olduğunu ileri sürerek, bundan gurur duymaktadırlar. Kendi özgül tarihlerinde, ağanın öldürülmesi pahasına çiftliğin dă̆ılmasına yol açan olayları sahiplenerek, kimliğini sosyal, ekonomik, siyasal anlamda yeniden inşa eden Baladızlıların, yeni yönetimsel oluşumlar karşısında da alan mücadelesine girmekten kaçınmadıkları görülmektedir. Dolayısıyla yukarıda sözleri alıntılanan görüşmecinin 'kabullenemiyorum' sözü hem yapılaşmış kimliğini koruma stratejisiyle davrandığının, ama aynı zamanda köy statüsünden mahalle statüsüne geçip geçmeme mücadelesinde içinde yer aldığı konumu kaybettiğinin bir ifadesidir. 
Köyün arazileri üzerinde devlet eliyle gerçekleşmiş bazı yatırımların (havaalanı, organize sanayi bölgesi) yarattığı itici güce ve görece erken bir tarihte örgün eğitim süreçlerine katılmalarına bağlı olarak Baladız'ın yerleşimcileri arasında farklı sosyal, kültürel ve ekonomik sermaye birikimine sahip eyleyiciler vardır. Bunlardan bazıları Baladız'da yaşarken Organize Sanayi Bölgesinde, Devlet Demir Yollarında, çimento fabrikasında, vd. çalışan, bazıları göç etse de köyle bağını koparmayan işçilerdir, memurlardır, öğretmenlerdir, vd.

Daha önce vurgulandığı gibi, bireylerin sosyal ve kültürel sermayesinin gelişiminde katkı sunduğu bilinen okulların ilk basamağı olarak Baladız ilkokulu, 1929 yılında köylüler tarafından yapılmış ve 17 öğrenci ile eğitime başlamış; 1933-1938 yılları arasında kapanan okul, 1939'da eğitim-öğretim faaliyetlerine yeniden başlamıştır. Erken Cumhuriyet döneminde, okuryazarlık oranının \%10 gibi son derece düşük olduğu bir toplumda, Köy Eğitmenleri Kanunu (1937), Köy Enstitüleri Kanunu (1940) gibi bir dizi kanun ve uygulamalarla okullaşmanın kırsal alanlarda da yaygınlaştırılmaya çalışıldığı bilinmektedir (Aysal, 2005). Özellikle bir tür kalkınma modeli olarak geliştirilen köy enstitülerinin temel işlevinin kırsal alanlardaki eyleyicilerin yapılaşmış habitusunu dönüştürmek olduğu söylenebilir. Bu amaçla 1939 yılında kurulmuş olan Gönen Köy Enstitüsü, yetiştirdiği öğretmenler ile civar il ve ilçelerin yanı sıra Baladızlı kız ve erkek çocukların okullaşması yönünde önemli bir etkisi olmuştur. Örneğin, 1942 yılına ait verilere göre, Baladız'da erkek öğrenci sayısı 27 iken, kız öğrenci sayıs1 11'dir (Tığl1, 1944:1777). İlkokul sonrası okullaşma sürecinde, yine bu enstitünün sunduğu rol modeller, Baladızlıların tarım dışı alanlarda da varlık göstermesine, meslek edinmesine yol açtığı görülmektedir. Günümüzde ise, tarımla uğraşan genç nüfus artık neredeyse kalmamıştır: 'Gençler okuyor... Bizim burada araziyle mücadele edecek yetişkin genç yok, hep bizim gibi yaşlılar var.'

Köyün mekânına yansımış temel farklılık, eski köy yerleşimcileri ile bir miktar arazinin el değiştirmesiyle oluşan yeni köy yerleşimcileri arasında görülmektedir. Görüşmecilere göre, '30-40 sene kadar evvel' 
ekonomik sermaye çıkmazını 'yabancılar'dan borç alarak çözmeye çalışan bazı Baladızlıların borçlarını ödeyemeyince arazilerini satması, bazen 'Abdal' bazen 'Çingene' dedikleri 6-7 hanenin köye gelip yerleşmesi ve bu ailelerin sayısının zamanla 70-80 haneye çıkmasıyla sonuçlanmış. Böylece inancıyla, destanıyla kimliğini inşa eden Baladızlı ile toplumsal ve mekânsal alanda karşıt bir şekilde konumlanmış başka bir grubun varlığı iki ayrı habitusun iki ayrı yerde yaşama pratiği geliştirmesine yol açmıştır. Bu durumda, köy-içi gerilimlerin yaşanması, toplumsal uzamların keskinleşmesi, yerli ve yabancı olarak iki ayrı strateji alanının oluşması ve dolayısıyla simgesel sermayeye atfedilen değerin hayli önemsenmesi şaşırtıcı değildir.

Öncelik-sonralık, yerlilik-yabancılık, Alevilik-Abdallık/ Çingenelik gibi farklı bağlamlara göre kurulan bu karşıtlık ilişkisine, son yıllarda köye geri dönenlerin veya tatil günleri için kullananların oluşturduğu bir katmanın daha eklendiği söylenebilir. Bu kesimi oluşturan eyleyicilerin fiziki mekândaki konumlanışı köyün güneye kayan en uç kısmındadır. Eğitim yoluyla kültürel ve sosyal sermaye birikimi köyün diğer kesimlerinden daha fazla olan bu grup, yapılan görüşmelerden anlaşıldığı üzere, ‘çöplerin toplanması' gibi taleplerle kentlilik değerlerini, alışkanlıklarını benimsemiş görünmektedirler. Bu nedenle mahalle statüsüne geçip geçmeme mücadelesinde köyün 'yabancı' addedilen ikinci katmanı ile ortak bir stratejiyi hayata geçirdikleri söylenebilir. Bazen üçüncü katmandan bir görüşmecinin Toplu Konut İdaresi’nin (TOKİ) köy yerleşimine konut yapması arzusunda, bazen ikinci katmandan bir görüşmecinin 'AVM gelse iyi olur. Şimdi burada yer alındı, yakında yapılacak' ifadesinde olduğu gibi, takipçi konumunda olanların alan mücadelesinde neden bir arada hareket ettikleri daha anlaşılır olmaktadır. Bir başka deyişle, bu ortak stratejide, ekonomik sermayeyi arttırmaya yönelik bir güdülenmenin önemli bir payı olduğu söylenebilir. Dolayısıyla ikinci ve üçüncü katmandan bazı eyleyicilerin talep ettikleri ekonomik yatırımların gerçekleşmesinin köyün mahalle statüsüne geçmesiyle kolaylaşacağ düşüncesi onların bir arada hareket ederek, yerleşik örüntüden ayrılmasına yol açtığı görülmektedir. Benimsedikleri mekânsal tasavvur ve eylem hatları sadece Baladızlı eski yerleşimcilerden değil, aynı zamanda dayanışmacı bir tutumla köy 
yapısını koruma stratejini uygulayan Kızılcıklılardan da farklıdır. Ancak köyün mahalle statüsüne geçmesinin yarattığı koşullar daha önce yaşanmayan türden sorunları beraberinde taşımaktadır. Bu da yeni bir gerilim kaynağı olarak alan mücadelesindeki yerini alacakmış gibi durmaktadır:

Burda köy yaşantısı var, 10-15 [bin] lira biriktiren ev yapıyor, belediye olunca o parası bu parası, ev yapamıyorsun. Bana göre yanlış oldu... [Hayvanların] bir kısmını dağa çıkaracak [yerleşim alanında hayvancılık yapmanın yasaklanması], bir kısmı köyde kaldı. Çingenelere denemiyor, köylüleri [Baladız kökenliler] çıkardılar. Ne gerekçeyle çıkarıyor, zarar veriyor bahçelere diye. Bir senedir böyle, belediye tutturduğundan beri böyle.

\section{İğdecik Köyü: 'Küçük İstanbul'}

İğdecikli görüşmecilerin köyleri hakkındaki anlatılarının ana teması, kendi yaşam pratiklerinin kentsel yaşam pratikleriyle benzerliği üzerinedir: 'Siyah-beyaz televizyon ilk çıktığı zaman tepeye alıcı-verici kurduk, rahat televizyon seyredebiliyorduk. Şimdi postaya bakıyorum en az on tane internet faturası çıkıyor. Zamanında ne varsa bizim köyde de var.' İğdecikli köylülerin kentsel yaşam tarzını yapılaştırıcı habitus olarak benimseyip, kendi hayatlarının dokusuna geçirmeleri köyleriyle ilgili sundukları imgelemde de ifadesini bulmaktadır: 'Küçük İstanbul.' Bununla anlatılmak istenen şey sadece kentsel yaşam pratikleri değildir, aynı zamanda toplumsal ilişkilerin cinsiyetçi bir ayrıma dayanmadan kurulabildiği köy-içi sosyal etkinliklerdir. Görüşmelerin bir kısmının gerçekleştirildiği köy kahvesinde kadınlar da yer almış, köy içinde rahat hareket edebildiklerini, sinema, tiyatro ve eğlence gibi köy etkinliklerinde yer aldıklarını belirtmişlerdir. Eski anlamını, işılevini yitirmiş büyük bir konağın zemin katının bir vakitler film gösterileri için kullanılmış olması, 'Küçük İstanbul' imgesini pekiştiren bir örnek olarak verilmektedir. Ancak bu türden etkinliklerin artık gerçekleştirilemediği, bu bitişe 'gidenler'in neden olduğu vurgusu ile, aslında, kültürel sermaye birikimindeki kayıp ifade edilmektedir: ‘30 yıl önce burası Küçük İstanbul'du. İyi insanlar gitti köy laçkalaştı.' 
İğdecik köyü, bugünkü ismiyle ilk defa 1500/01 tarihli 30 numaralı Defter-i Hakani kaydında, Baladı'la birlikte yer almaktadır. Buna göre, Gönen kazasına bağlı İğdecik köyü 35 hanelidir (Dağlığlu, 1941:1127). Baladız gibi İğdecik köyü sakinlerinin de kıtlık, veba gibi nedenlerle göç ettiği ve köyün bir yüz yıl kadar "boz ve muattal" kaldığı yerel tarihçilerin Osmanlı kayıtlarından derledikleri bilgiler arasındadır (Yörükoğlu, 1949:2299).

Bu köyün özgül tarihini 18. yüzyıldan itibaren biraz daha yakından izleyebilmekteyiz. Mutasarrıf Çelik Mehmet Paşa dairesinde çalışan Lek aşiretinden Zülfikar Ağa'nın arzusu üzerine, Çelik Paşa çiftliklerinden İğdecik'e ait dört bin dönümden fazla arazinin zemin resmini (dönüm vergisi) vermek şartıyla bu kişiye ve kardeşlerine tahsisatı (1737/ 38) yoluna gidilmiştir (Böcüzade, 2012:54). Bir başka deyişle, Resul Paşa'nın oğullarından Zülfikar Ağa ve iki erkek kardeşi, Bağdat'ta, Murat nehri civarında yaşarken yarattıkları huzursuzluklar nedeniyle I. Mahmut tarafından Burdur'a sürülmelerinin ardından (Yörükoğlu, 1949:2299), Çelik Mehmet Paşanın sağladığı imkân ve kendilerinin seçimiyle İğdecik'i yeniden inşa etmişler ve günümüze kadar ulaşmasını sağlamışlardır. Bu süreçte ortakçı/kiracı köylülerin bu çiftliğin asli unsurları arasında oldukları kabul edilebilir. Yörükoğlu'nun (1949:2300) monografisine göre, İğdecik ovası çobanlık yapmak, elma toplamak, vb amacıyla veya kıtlı gibi afetler sonucu gelenler için her zaman bir çekim merkezi olmuştur. Uluborlu'dan gelmiş Sarıkeçili Yörükler, Anamas'tan gelmiş Hayta Yörükleri, Keçiborlu'dan göç edenler, bir Kürt aileden çoğalanlar, vd. İğdecik'in şu anki yerleşimcileri arasındadır.

Yerli İğdeciklilerden bazılarının çizdikleri şecerelerle, yazdıkları monografilerle soydanlık bağını Resul Paşa'nın oğullarına dayandırdıkları görülmektedir. Kendilerini kurucu aileye bağlayan İğdecikliler açısından, sülalenin simgesel sermaye değerini gösteren diğer bir unsur, sivil mimari açısından Isparta yöresinde bir benzeri görülmeyen büyük bir konağa sahip olmalarıdır. Köy anlatıları arasında 'Büyük Ev' dedikleri bu konağın Resul Paşa sülalesinden Hafız Mustafa Efendi tarafından ‘1313 yılında’ [1895/96] yaptırıldığı, oğlu Hacı Süleyman Efendi’nin birinci derece mirasçısı olmadığından ikinci derece 
mirasçılarına geçtiği yer almaktadır. İğdecik ağası Süleyman Efendi'nin toplumsal konumunu pekiştiren bir mekân olarak konak, Bourdieu'nun (2015:224) perspektifinden, toplumsal uzamdaki karşıtlıkların, hiyerarşinin, toplumsal mesafenin açık bir ifadesidir. Ahşap ve alçı tavan süslemeleriyle bir dönemin beğenisini yansıtan bu konakta, anlatımlara göre, Isparta eşrafından, idari bürokrasiden birçok kişi ağırlanmış, akraba düğünleri gerçekleştirilmiştir. ${ }^{11}$ Konağın zemin katı ise, köylülerin düğün/kına geceleri ve 1970’lere kadar film gösterileri için kullanılarak köy-içi etkinliklerin çekim merkezi olmuş; köylülerin sosyal-kültürel sermayesinin de bir parçası haline gelmiştir.

Diğer yandan, 1914 yılındaki Isparta depremi nedeniyle Kılıç köyünden gelerek İğdecik'in kompozisyonuna katılan bir başka etkin kişi, Hafız Nuri Efendidir. Torunlarından birinin anlatımına göre, İğdecik'te büyük miktarda arazi satın alan ve Resul Paşa sülalesine damat olan Hafız Nuri Efendi, geldiği tarihten itibaren ‘köyün ağası' olur. Birkaç kere evlenen, her evlilikte geline birkaç yüz dönüm tarla veren, çiftlik kâhyasının çocuğu sünnet olduğunda 'sünnetlik tarla' bağışlayan bir kişi olarak, Baladız'ın çiftlik ağasının davranış kalıplarının epey dışındadır. Bu özelliklerinden dolayı Nuri Efendi, torununa göre, İğdecik’te 'ağalığı bitirip, herkesi ağa yapmıştır.'

İğdecik’in bir ağa köyünden çok bir ahali köyü görünümüne kavuşması, birkaç nedene bağlanabilir. 20. yüzyılın ikinci çeyreğinden itibaren ağa ailesinden birçok kişinin örgün eğitim yoluyla kazandıkları sosyal, kültürel ve ekonomik sermayelerinin peşinden giderek, İğdecik dışında yaşamaya başlamaları ve miras yoluyla edindikleri arazilerini peyderpey köylülere satmaları; küçük ölçekli araziye sahip veya ortakçı/ kiracı köylülerin çocuklarının da birer meslek edinmek amacıyla örgün eğitim süreçlerine yoğun bir şekilde dâhil olmaları ve giderek kırsal üretimden kopmaları; köylülerin Tarım-Kredi Kooperatifi ve Ziraat

\footnotetext{
${ }^{11}$ Kurtuluş Savaşı'nın dikkat çekici figürlerinden Demirci Mehmet Efe 1920'de İğdecik'e gelerek, karargâh ve ikametgâh olarak kullanmak üzere bu konağı işgal eder ve yedi ay burada kalır (Yörükoğlu, 1949:2300). İğdecikli görüşmeciler de konağ1 sahibinden çok Demirci Efe üzerinden hikâye etmektedirler.
}

$\mathrm{SAD} / \mathrm{JSR}$

Cilt / Volume 20 Sayı / Number 1 
Bankası'nın verdiği kredileri ödemekteki güçlükleri veya kişisel borçlanmaların arazilerin el değiştirmesine yol açması, köy popülasyonundaki devingenliğin birer nedeni olarak gösterilebilir (Yörükoğlu, 1949).

İğdeciklilerin oldukça erken bir tarihte okullaşmayı sermaye türlerinin hacmini artırıcı bir eylem hattı olarak benimsemeleri, kendilerini diğer iki köyden önemli derecede ayırmaktadır. Yörükoğlu’un (1949:2301) aktardığına göre, İğdecik’teki ilk resmi okul 1903 yılında köylüler tarafından yapılmış; ilerleyen yıllarda, 1945 'de yeniden inşa edilmiştir. Aynı kaynakta, okuldan mezun olan öğrencilerin sayısı da verilmektedir: 1924 ile 1949 yılları arasında toplam 47 erkek öğrenciye karşın, 42 kız öğrencinin mezun olduğu; 1949 yılında köyde okuma yazma bilenlerin oranının \%95 olduğu belirtilmektedir. Özetle, köy ilkokulundan mezun olanların Köy Enstitüsü, Erkek Sanat Enstitüsü, Harp Okulu, Tıbbiye gibi eğitim basamaklarında ilerleme yönünde teşvik gördükleri anlaşılmaktadır (Yörükoğlu, 1949:2302). Askeri personel, öğretmen, avukat, memur, öğretim üyesi gibi beyaz yakalı pek çok sayıdaki İğdeciklinin kendilerinden sonrakilere birer rol model oldukları; bu kişilerden bazılarının Almanya gibi çeşitli ülkelere öğrenim ve/veya çalışma amaçlı giderek, yurt dışı deneyimi kazanmalarının İğdeciklilerin gelecek tasavvurlarını şekillendirdikleri söylenebilir. Böylece, bir görüşmecinin ifadesiyle, 'ağa çocuğu [da] memur olmuştur.'

Gönen Köy Enstitüsü vardı, muazzamdı. Oraya hareketlilik getirdi, öğretmen yetiştirdi. Bizim köyden çok okuyan oldu, hep köy çocukları öğretmen oldu... O öğretmenler bize [konağa] misafirliğe gelirdi. Cumartesi Pazar kalır giderlerdi. O zaman Gönen çok canlıydı.

Gönen Köy Enstitüsü’nün mezun-stajer öğretmenleri vardı. Buraya gelirlerdi stajer olarak. Kültürlü insanlar etkiledi. Köyden köy enstitüsü mezunları var. Bir iki yıl okuyup terk edenlerin bile davranışları değişmişti.

Sonuçta, sermaye tür ve hacmini artırmak yönünde kullanılan bu eylem hattının, İğdeciklilerin tarımsal üretimden koparak kentsel alanlara göç etmesine ve köyde kalanlardan farklı bir birikime sahip olmalarına yol açmıştır. Yukarıda, '..Iyi insanlar gitti köy laçkalaştı' diyen görüşmeci sadece kültürel kayba vurgu 
yapmamakta aynı zamanda farklı sermaye türlerinin birikiminin yarattığı toplumsal uzam farkına da işaret etmektedir.

Son y1llarda gözlenen yeni eğilim, eski İğdeciklilerin emekli olarak köye dönmeleri veya bir sayfiye yeriymiş gibi yaz aylarında kısa süreli gelmeleridir. Bu kişilerin yaptıkları yeni konutlar, köy yerleşim alanının kuzey yamaçlardan ovaya doğru yayılmasına yol açmıştır. Farklı sermaye hacimlerine sahip bu grup aynı köyden olma deneyimini paylaşmakla birlikte, köyde yerleştikleri alanlar, konut tipleri ve inşaat malzemesi, vb ile diğerlerinden farklılaştıkları izlenebilmektedir. Eski İğdecikliler ile geri dönenlerin oluşturduğu bu mekânsal ayrım bir alan mücadelesini yaratmasa da, görece bir toplumsal katmanlaşmaya işaret etmektedir. Örneğin, yaşadığı konutu diğer konutlarla karşılaştıran bir görüşmeci, 'gelenim gidenim için, çevrem için problem, onların evine gidiyorum daha kullanışlı, ahım şahım' diyerek memnuniyetsizliğini ortaya koyarken aynı zamanda kendi beğenisindeki değişmeyi de göstermektedir.

Beğenilerdeki değişim, göç etmiş ancak '[İğdecikle] irtibat halinde' olan eski İğdeciklilerin etkisi bir yana, köylülerin kentle kurduğu çeşitli düzeylerdeki kesintisiz ilişkiye bağlanabilir. Bir başka deyişle, kentsel orta-sınıf beğenilerin, tüketim alışkanlıklarının, konut tercihlerinin köye taşınmasındaki başlıca etken, eyleyicilerin hem sermaye türlerini artırmak yönünde örgün eğitim süreçlerine katılmaları hem de kültür taşıyıcılarıyla sürekli etkileşim halinde olmalarıdır. Örneğin, eğlence kültürü veya tüketim alışkanlıklarına dair bazı ifadeler şöyledir: 'Biz buradan kalkıp sinemaya gidip gelebiliyoruz' veya 'Şehirdekiyle aynı bi fark yok ki. Şu İğdecik köyünde kendi ekip biçip yiyen 100 kişiden 30'u, kalanı pazara [Gönen] gidiyo.'

Diğer yandan, köylülerin Abdallar gibi dış grup olarak tanımladıkları kişi ve gruplara karşı akrabalık ve sosyal ilişkiler yoluyla dayanışmacı bir tavır sergiledikleri görülmektedir. Özellikle farklı etnik gruptan olanların köy kaynaklarına yönelik hırsızlık gibi girişimleri köy-içi dayanışmayı artırmaktadır. Ancak emeklilik sonrası geri dönenler ile ailesinin mülkiyetinde kendine bir konut yapan genç İ̆gdecikliler, bu dayanışma ağının bir parçası olmakla birlikte köy içi kararlarda takipçi konumunda oldukları söylenebilir.

$\mathrm{SAD} / \mathrm{JSR}$

Cilt / Volume 20 Sayı / Number 1 
Kısaca, iç grubun selametini sağlamak ve bütünlüğünü korumak için bazı dış gruplara karşı tetikte olsalar da, köy arazisinden herhangi bir satış söz konusu olduğunda dış gruptan bir kişinin bunu satın almasını engelleyemedikleri görüşmecilerin anlatımlardan anlaşılmaktadır: "Sattırmamaya gayret ediyoruz ama alan var. Parası olan topluyor. Ekseriye Ispartalı. Almanyalı da biri var. Bir sürü arazi almış el altından.”

Özetle, İğdecikte gözlenen kırsal değişimin kentleşme süreçlerinin bir uzantısı olarak gerçekleştiği söylenebilir. Bu süreçte anahtar figürler, örgün eğitime verdiği destekle Süleyman Efendi ve Hafız Nuri Efendi, Gönen Köy Enstitüsü, öğretmenler ve köyün eğitimli rol modelleridir. Bu eylem hattının dönüştürücü etkisinin yanı sıra büyük arazilerin parçalanarak mülkiyet ilişkilerinin de değiştiğine tanık olunmaktadır. $\mathrm{Bu}$ iki sürecin birbirine paralel geliştiği düşünülse de, büyük arazilerin parçalanması muhtemelen daha önce başlamıştı. Aksi takdirde, Hafız Nuri Efendi kendisini 'ağa' statüsüne taşıyacak büyük ölçekli araziyi 1914 gibi erken bir tarihte edinemezdi. Dolayısıyla, İğdeciklilerin kentsel yaşam tarzıyla bezenmiş toplumsal uzamlarının görünümlerinin köylülük veya köyün içsel yapısı ile sınırlandırılamayacak kadar geçişken olduğu söylenebilir. 


\section{SONUÇ}

Kırsal değişime Bourdieucü bir perspektifle odaklanılan bu araştırmada, üzerinde alan çalışması yapılan köylerin son yüz elli yıl içinde konar-göçer iskânı, 3116 sayılı Orman Kanunu, 4753 sayılı Çiftçiyi Topraklandırma Kanunu, 6360 sayılı Büyükşehir Belediyesi Kanunu gibi devlet eliyle gerçekleştirilmiş çeşitli kanun ve uygulamalarla karşı karşıya geldikleri saptanmıştır. Bu türden dönüştürücü planlamaları yine kendilerinin tarihsel olarak benimsedikleri eylem hatlarıla ve farklı uyarlanma stratejileriyle karşılamaya çalıştıkları görülmüştür. Bir başka deyişle, her üç köyde, yapılaşmış habitusları doğrultusunda geliştirdikleri çeşitli stratejiler ile değişme sürecini yönetmeye, yönlendirmeye çalıştıkları gözlemlenmiştir.

Kentsel toplumlara özgü olduğu kabul edilen farklı sermaye tür ve hacimlerine sahip bireylerin gerçekleştirdikleri alan mücadelesinin bu üç kırsal yerleşimde görece var olduğu söylenebilir. Kısaca belirtmek gerekirse, Yörüklük kimliğinden kaynaklanan toplumsal uzam farklılığının ve bunun yarattığı dışlayıcı algıların bilincinde olan Kızılcıklılar, sürü ekonomisine dayalı göçebeliği/ yaylacılığı bir eylem hattı olarak sürdürmeye çalışırken, farklı sermaye tür ve hacmine sahip dış-gruptan bireylerin arazi satın alma taleplerine karşı mülkiyetin el değiştirmesi konusunda korumacı davrandıkları gözlenmiştir. Geçmişte ağa-ortakçı/kiracı ilişkisinin gerilimli bir şekilde yaşandığı Baladız ise, toprağın mülkiyetine sahip olmak amacıyla zorlu bir alan mücadelesine girildiğinin açık örnekleriyle doludur. Yakın zamanda büyük ölçekli ekonomik projelerin değişim yönündeki etkileri karşısında, sahip olunan ekonomik ve sosyal sermayeyi arttırmak amacıyla farklı toplumsal kurum ve yapılarla işbirliğine girildiği ve yeni strateji biçimlerinin eylem hatlarına dâhil edildiği bulgularımız arasındadır. Dolayısıyla arazilerin tarım-dışı faaliyetlere açık hale gelmesinin toprak mülkiyetinin yeniden el değiştirmesinin arkasındaki başlıca neden olduğu görülmektedir.

Bir yüzyıllık süreç içinde yapılaştırıcı bir eylem hattı olarak örgün eğitimi en fazla benimsemiş olan köy, İğdecik'tir. Devlet eliyle gerçekleştirilen ekonomik projelere ev sahipliği yapmasa da, kültürel sermayeleri 
sayesinde kentle ve onun imkân ve araçları ile kurdukları sıkı bağların kentli orta-sınıf beğenilerinin, tüketim alışkanlıklarının yaygın bir şekilde benimsenmesine yol açtığı söylenebilir. Ayrıca, tarımsal işletmelerin zamanla küçülmesi ve yüksek oranda eğitimli-diplomalı nüfusa sahip olması gibi nedenler hem görece erken tarihlerde toprak mülkiyetinin el değiştirmesine hem de yeni nüfus gruplarının köyün kompozisyonuna dâhil olmasına yol açtığı söylenebilir.

Her üç köyde de toplumsal uzam farkl1lıklarının görünümü köy içindeki mekânsal yer seçimlerinde izlenebilmektedir. Kızılcık’ta köyün merkezine değil de çepere yerleşen birkaç yabacı aile, Baladız ve İğdecik’te yeni gelişme bölgelerine yerleşenlerin köy içindeki konumlanışı, aslında, yabandan gelenler ile eski yerleşimciler arasındaki toplumsal uzam farklılığının mekânsal gelişim şemasına yansıyan izdüşümü olarak kabul edilebilir.

Sonuçta, tarihsel olarak aynı lineer aks üzerinde bulunan bu üç köy örneğinden hareketle, kırsal alanların statik ve türdeş yapılara sahip olduğu düşüncesiyle bunların tek-yönlü belirlenimci bir yaklaşımla ele alınamayacağını, dolayısıyla dönüştürücü kırsal planlama çalışmalarının geleneksel-modern türünden ikilikleri aşacak şekilde kırsal çeşitliliği dikkate alması gerektiğini ileri sürebiliriz. Diğer yandan, iş ve eğitim, ticari alışveriş, göç, vb yoluyla kentsel alanlarla kurdukları ilişkilerin yoğunluğu, tüm çeşitliliğine rağmen kırsal alanların kentsel dinamiklerden bağımsız düşünülemeyeceğini de ortaya koymaktadır. Bir başka deyişle, kırsal alanları, çevreyle kurdukları tüm sosyal, kültürel, ekonomik, siyasi, vb ilişkileri içinde tarihsel-bütüncül bir perspektifle ele almanın gereği açıktır.

$\mathrm{SAD} / \mathrm{JSR}$

Cilt / Volume 20 Say / Number 1 


\section{SUMMARY}

The present study seeks an answer to the question of how agents' adaptation strategies in different rural settings vary in response to the transformative activity of exogenous factors in three different rural settlement contexts. Furthermore, the present study refers to the revealing perspective of Bourdieu's theory of action that treats the individual as an active agent in an attempt to understand forms of adaptation, resistance or developing counter-strategies to change. In the field research carried out using the in-depth interview and direct observation techniques between 2013 and 2016, the difference of change in the K1z1lc1k, Baladız (Gümüşgün), and İğdecik Villages, affiliated to Gönen district of Isparta province, was sought in the differences along the lines of action historically internalized by the local agents and in their strategies of adaptation based on the type and volume of the capital they had.

It was observed that these three villages, which have been confronted with various laws and practices enacted and carried out by the state such as the settlement of nomads, the Law on the Provision of Farmers with Land, the Law on Village Institutes, and the Metropolitan Municipality Law throughout the last one hundred and fifty years, have attempted to manage and direct the process of change by means of various strategies they developed. It was found that the transhumance activities based on an economy of flock have maintained themselves as a line of action in Kız1lc1k; locals in Baladız have recently been in pursuit of economic and social capital gain offered by large-scale economic projects following some hard land struggle undertaken for the ownership of land, and İğdecik, which adopted formal education as a structuring line of action to the greatest extent, brought the urban middle-class tastes and consumption habits to the rural area thanks to its cultural capital.

Expressed in all three villages and also reflected in the shaping of space therein, the metaphor of the 'outsider' indicates various appearances of the difference in the social space between residents and those who immigrated to the village as well as those who returned to the village after a period of emigration. 
Considering these data, it was suggested that the rural areas did not present static or homogeneous structures and that the rural planning studies should take rural diversity into consideration to overcome traditionalmodern type of dichotomies. 


\section{KAYNAKÇA}

Akdağ, M. (1963). Osmanlı Tarihinde Âyanlık Düzeni Devri 1730-1839. Ankara Üniversitesi Dil ve TarihCoğrafya Fakültesi Tarih Bölümü Tarih Araştırmaları Dergisi, 8 (14), 51-61.

Akşit, B. (2006). Köy, Kırsal Kalkınma ve Kırsal Hanehalkı/ Aile Araştırmaları: 1923-2002 Yılları Arası Eleştirel Bir Yazın Taraması. Ayda Eraydın (Ed.), Değişen Mekân-Mekânsal Süreçlere İlişkin Tartışma ve Araştırmalara Toplu Bakış: 1923-2003 içinde (s. 123-163). Ankara: Dost.

Arıkan, Z. (1988). XV-XVI. Yüzyıllarda Hamit Sancağı. İzmir: Ege Üniversitesi.

Armağan, A. (2008). XV. ve XVI. Yüzyıllarda Teke Sancağı'nda Konar-Göçerler: Sosyo-Ekonomik ve Demografik Durumları. Hayati Beşirli, İbrahim Erdal (Ed.), Osmanlı'dan Günümüze Yörükler ve Türkmenler içinde (s. 71-127). Ankara: Phoenix.

Aydın, S., Yağcı, M. (2013). Sarıkeçililerin 'Eşkıyalı̆̆ı’ve Konya Delibaş İsyanı Üzerine Değinmeler. Kebikeç, 35, 59-112.

Aysal, N. (2005). Anadolu'da Aydınlanma Hareketinin Doğuşu: Köy Enstitüleri. Ankara Üniversitesi Türk İnklâp Tarihi Enstitüsü Atatürk Yolu Dergisi, 35-36, 267-282.

Balta, E. (2002). 1945 Çiftçiyi Topraklandırma Kanunu: Reform mu Karşı Reform mu. Praksis, 5, 277-298.

Barkan, Ö. L. (1980). Türkiye’de Toprak Meselesi. İstanbul: Gözlem.

Bates, D. G. (2009). 21. Yüzyılda Kültürel Antropoloji İnsanın Doğadaki Yeri (1. Baskı) Suavi Aydın vd.(Çev.) İstanbul: İstanbul Bilgi Üniversitesi.

Bazin, M. (1993). Orta Toros Yörüklerinden Sarıkeçili Aşireti. Hamdi Kara (Çev.). Ankara Üniversitesi Türkiye Coğrafyası Araştırma ve Uygulama Merkezi Dergisi, 3, 323-351.

Birtek, F., Keyder, Ç. (1976). Türkiye'de Devlet-Tarım İlişkileri 1923-1950. Nur İmer (Çev.). Birikim, 22, $31-40$.

Bourdieu, P. (1995). Pratik Nedenler/ Eylem Kuramı Üzerine (1. Bask1). Hülya Tufan (Çev.). İstanbul: Kesit.

Bourdieu, P. (2009). Bekârlar Balosu. Çağn Eroğlu (Çev.). Ankara: Dost.

$\mathrm{SAD} / \mathrm{JSR}$

Cilt / Volume 20 Sayı / Number 1 
Bourdieu, P. (2015). Mekân Etkisi. Pierre Bourdieu, vd. Dünyanın Sefaleti içinde (s. 223-233). Levent Ünsaldı vd. (Çev.). İstanbul: Heretik.

Bourdieu, P., Wacquant L.J.D. (2003). Düşünümsel Bir Antropoloji İçin Cevaplar (1. Baskı). Nazlı Ökten (Çev.). İstanbul: İletişim.

Böcüzade, S. S. (2012). Isparta Tarihi. Hasan Babacan (Haz.). Isparta: Isparta Valiliğii.

Dağlıoğlu, H. T. (1941). Hicri X uncu Asırda (Hamideli)nde Arazi, Hasılat, Nüfus ve Aşiretlerin Vaziyetleri ile Vergi Sistemleri III. Ün Dergisi, 7 (82-83), 1121-1127.

Emirbayer, M., Williams, E. M. (2005). Bourdieu and Social Work, Social Service Review, 79 (4) (December), 689-724.

Erdal, S. (2011). Baladız'ın Hikâyesi ve Din ile İnsanlık Üzerine Yazılar. Isparta.

Gümüş, C. (2014). Osmanlıdan Günümüze Ormancılık Politikalarının Ormancılık Örgütlenmesi Üzerine Etkileri ve Güncel Sorunlar. II. Ulusal Akdeniz Orman ve Çevre Sempozyumu: Akdeniz Ormanlarının Geleceği: Sürdürülebilir Toplum ve Çevre, Isparta, 477-489. (Ormanweb.sdu.edu.tr/ormanvecevre/belgeler/bildiriler/48_A4-1.pdf)

Isparta Cinayeti Hakkında Bakanlığın Tebliği. (20.8.1946) Cumhuriyet Gazetesi. cumhuriyetarsivi.com.

İnalcık, H. (1998). Çiftliklerin Doğuşu: Devlet, Toprak Sahipleri ve Kiracılar. Çağlar Keyder, Faruk Tabak (Der.). Osmanlı'da Toprak Mülkiyeti ve Ticari Tarım içinde (s. 17-35). İstanbul: Tarih Vakfi.

Karaömeroğlu, M. A. (1998). Bir Tepeden Reform Denemesi: “Çiftçiyi Topraklandırma Kanunu’nun Hikâyesi”. Birikim, 107, 31-47.

Kasaba, R. (1993). Osmanlı Imparatorluğu ve Dünya Ekonomisi-On Dokuzuncu Yüzyll (1.Bask1). Kudret Emiroğlu (Çev.). İstanbul: Belge.

Kaya, A. (2007). Pierre Bourdieu'nun Pratik Kuramının Kilidi: Alan Kavramı. Güney Çeğin, Emrah Göker, Alim Arlı, Ümit Tatlıcan (Ed.). Ocak ve Zanaat Pierre Bourdieu Derlemesi içinde (s. 392-419). İstanbul: İletişim.

Kepenek, Y., Yentürk, N. (2000). Türkiye Ekonomisi (10.baskı) İstanbul: Remzi. 
Keyder, Ç. (1985). Türkiye'de Ortakçılık Döngüsü ve Küçük Köylü Mülkiyetinin Pekişmesi. Yapıt Toplumsal Araştırmalar Dergisi, 11, Haziran-Temmuz, 89-105.

Keyder, Ç., Pamuk, Ş. (1984-85). 1945 Çiftçiyi Topraklandırma Kanunu Üzerine Tezler. Yapıt- Toplumsal Araştırmalar Dergisi, 8, 52-63.

Köse, N. (1935). Yı1lanlı Oğulları ve Çelik Paşalar. Ün Dergisi, 2 (19), 265-267.

Marcus, G. E. (1995). Ethnography in / of the World System: The Emergence of Multi-Sited Ethnography, Annual Review of Anthropology. 24, 95-117.

Meeker, M. E. (2005). Imparatorluktan Gelen Bir Ulus Türk Modernitesi ve Doğu Karadeniz'de Osmanlı Mirası. Tutku Vardağlı (Çev.). İstanbul: İstanbul Bilgi Üniversitesi.

Orhonlu, C. (1987). Osmanlı İmparatorluğu’nda Aşiretlerin İskânı (1.baskı) İstanbul: Eren.

Özer, S. (2013). Demokrat Parti’nin Köy ve Köylü Politikaları (1946-1960). Ankara: Berikan.

Savage, M. (2011). The Lost Urban Sociology of Pierre Bourdieu. Gary Bridge, Sophie Watson (Ed.). The New Blackwell Companion to the City içinde (s. 511-520). Blackwell Publishing Ltd,.

Swartz, D. (1997). Culture and Power the Sociology of Pierre Bourdieu (1.Basim). USA: The University of Chicago.

Tatlıcan, Ü., Çeğin, G. (2007). Bourdieu ve Giddens: Habitus ve Yapının İkiliği. Ocak ve Zanaat Pierre Bourdieu Derlemesi içinde (s. 303-366). Güney Çeğin, Emrah Göker, Alim Arlı, Ümit Tatlıcan (Ed.). İstanbul: İletişim.

Tığl1, T. (1944). Isparta ve Çevresi Köylerine Genel Bir Bakış VII. Ün Dergisi, 11 (127-128), 1775-1779.

Tuztaş H. A. H. (2014). Konup-Göçmek, Yerleşmek ve Yaşamak: Sarıkeçililerde Mekân ve Anlatı. Yayımlanmamış Doktora Tezi. Yeditepe Üniversitesi / Sosyal Bilimler Enstitüsü, İstanbul.

Yörükoğlu, A. R. (1949). İğdecik Köyü. Ün Dergisi, 13 (171-172), 2299-2302.

$\mathrm{SAD} / \mathrm{JSR}$

Cilt / Volume 20 Say1 / Number 1 